\title{
A Qualitative Study of Rehabilitation Professionals' Optimal Social Participation and Factors Perceived as Influencing
}

\author{
Luciana Braga and Annie Rochette
}

\author{
Centre for Interdisciplinary Research in Rehabilitation of Greater Montreal, Quebec, Canada \\ School of Rehabilitation, Faculty of medicine, University of Montreal, Quebec, Canada
}

\begin{abstract}
Introduction and Purpose: Optimal social participation, which is the ultimate goal targeted by rehabilitation professionals for their clients, can be defined as perfect congruence between an individual's expectations and reality. Work-family dynamic requires balance between the different spheres of a worker's life. The purpose is to explore the perception of rehabilitation professionals regarding their optimal social participation based on work-family conciliation, and the factors they identify as influencing this participation.
\end{abstract}

Method: Qualitative study with a phenomenological orientation among 13 rehabilitation professionals using an interview guide consisting of open questions. The data was audio-recorded and transcribed in full (verbatim) followed by content analysis. Analysis was carried out systematically to achieve a better understanding of the facts. A proportion of the analysis (approximately 10\%) was coded by another team member for validation.

Results: Participants were mostly women (12/13) aged 31 to 44 years having one to three children aged from 7 months to 12 years old. Optimality of participation is perceived as the ability (or not) to carry out important activities while fulfilling one's various responsibilities. Of the five environmental factors perceived to have an influence (financial aspects, spousal support, time, flexible work schedule, and family organization), family organization appears to be a determinant of possibility and thus greatly influences individual expectations.

Conclusion: Work-life balance is a complex phenomenon that should be studied holistically rather than in a segmented mode.

Keywords: Qualitative study, rehabilitation staff, social and leisure activities, social support, work, participation.

\section{INTRODUCTION}

An aging population has led to an increased demand for rehabilitation. At the same time, increased knowledge and a complexity of roles and responsibilities for rehabilitation professionals has led to greater pressure on the latter, combined with a lack of staffing in the majority of paramedical disciplines, which is reflected in longer waiting lists. Furthermore, the context of family life has changed in recent years. Work-family balance has become a major concern of populations (and governments), whether for raising young children, caring for a family member with a loss of autonomy, or both. These various environmental contexts have an influence on the social participation of rehabilitation professionals. Social participation is defined as the accomplishment of life habits, i.e., the activities of daily living and the social roles that ensure the survival and fulfillment of individuals [1,2]. While the ultimate goal of rehabilitation professionals is to promote optimal social participation among their clients, no study could be identified regarding the social participation of rehabilitation

*Address correspondence to this author at the School of Rehabilitation, Université de Montréal, C.P. 6128, Succursale Centre-Ville, Montréal, Québec, H3C 3J7, Canada; Tel: 514-343-2192; Fax: 514-343-2105;

E-mail: annie.rochette@umontreal.ca professionals themselves. Optimal social participation is desirable for rehabilitation professionals to ensure their personal fulfillment and to better enable them to provide quality services. This may be the case of the cobbler's children having shoes or not. This study aims to explore precisely the perception of rehabilitation professionals regarding their own level of social participation as experienced in their daily lives and as desirable in an ideal world.

\section{THE DISABILITY CREATION PROCESS (DCP) CONCEPTUAL MODEL}

The model underlying this study and used to organize the literature is the Disability Creation Process (DCP) [1]. As an anthropological model of human development, this model applies to everyone regardless of the presence or absence of health problems, thus allowing us to understand the integrity and development of people within the context of their lives (see Fig. 1). In the model, social participation is operationalized through the concept of life habits, which are influenced by an interactive process between personal factors (internal) and environmental factors (external). Life habits fall into two broad categories: 1) activities of daily living (nutrition, fitness, personal care, communication, housing, and mobility) and 2) social roles (responsibilities, relationships, community life, education, employment, and recreation). 


\section{Disability Creation Process Conceptual Scheme}

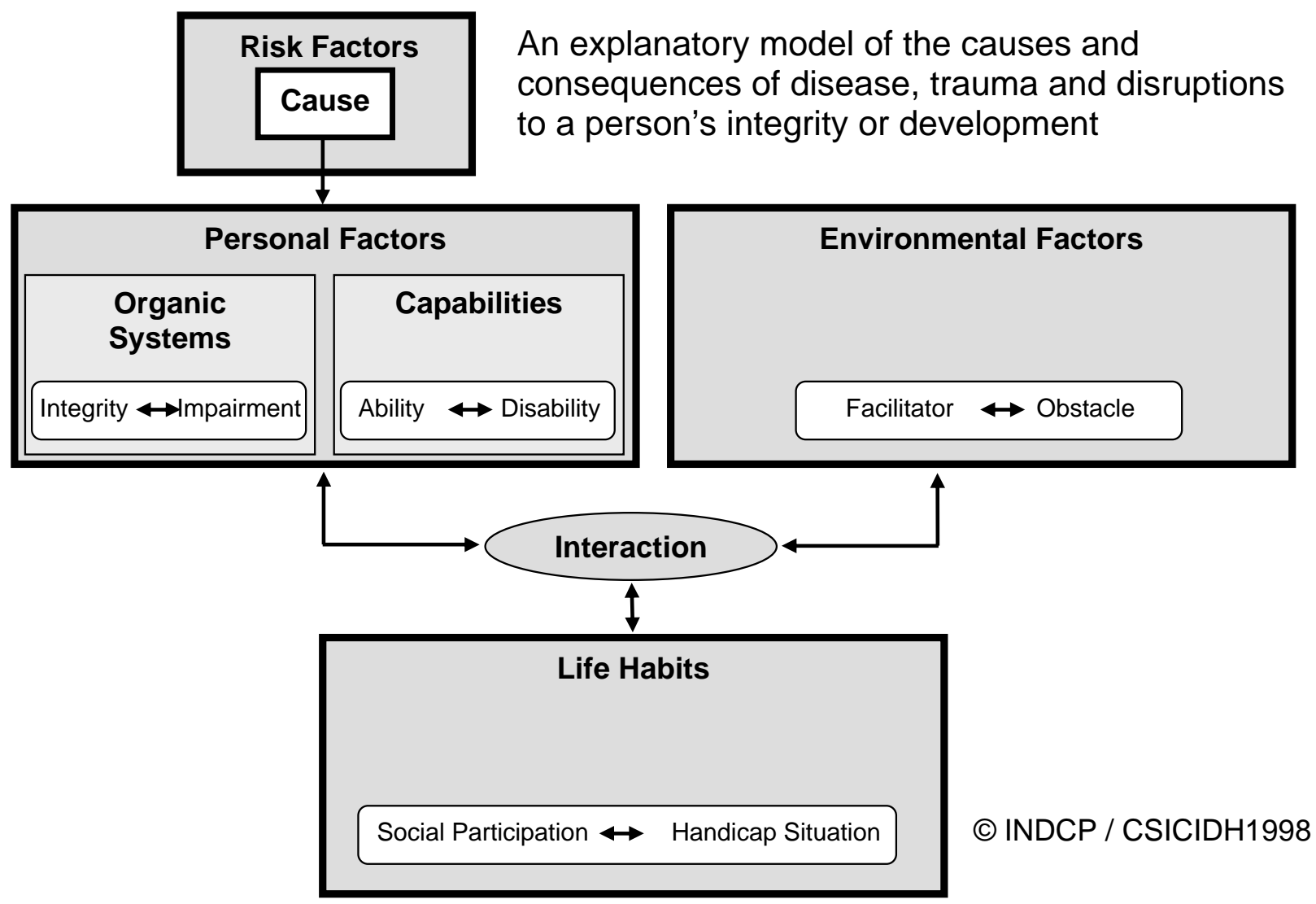

Fig. (1). The disability creation process conceptual model.

\section{LITERATURE REVIEW}

Work-life balance is a reality that affects many sectors of our society. A database search on the subject in Pubmed, PsycInfo, Francis, Repère, and Statistics Canada, for the period of 1980 to 2010 , using the keywords work-family conflict, work-life balance, social-environment, job stress, burnout, activities of daily living, health professionals, and family conflict, produced more than 300 articles related to health professionals, but none dealing specifically with rehabilitation professionals. The articles were selected for their relevance and the topic of work-family balance. Several studies addressed work-family conflict and its impact on family and professional life as a discord between these two spheres [2-9]. Among these articles, we found that the subject was studied in a segmented mode, i.e., the daily lives of workers, including all spheres of their lives, and the interinfluence between these spheres, was not taken into account. The brief literature review that follows is organized according to the DCP: articles categorized under personal factors relate to work-family balance and women, depression, stress, tiredness, exhaustion, and physical and psychological impact; and articles categorized under environmental factors relate to facilitators and barriers to the accomplishment of daily living, such as workplace flexibility, support from colleagues and superiors, workplace daycare facilities, and financial aspects. Finally, some studies specifically addressed life habits and work-life balance and included travel, family responsibilities, relationships, education, food, and recreation.

\section{PERSONAL FACTORS AND WORK-FAMILY BALANCE}

With economic development in most Western countries and the requirements of the labor market, increased demand for labor in the service sector has been observed [10]. This increase may have contributed to a growth in female participation in the labor market, traditionally involving a double responsibility of tasks, i.e., tasks related to work and those related to the home, including, among other things, caring for children [11]. In addition, the demands of work may cause adverse effects that manifest themselves in terms of the physical and psychological health of individuals, including tiredness, stress, insomnia, and depression, all of which can cause an emotional and relational deterioration between parent and child, especially for school-age children who are most affected by school failure [12-14]. On the 
other hand, several authors mention the problem of reconciling tasks and finding balance between personal, professional, and family responsibilities for many women [11, 15-18]. Moreover, increased family and work responsibilities cause exhaustion and psychological distress, which can often lead to personal and professional conflicts and personal dissatisfaction. Over time, the weight of distress increases and has an adverse effect on the health of individuals [19, 20]. Moreover, some studies show an accentuation of marital conflict, and the risk of divorce, with higher levels of stress $[6,7,21,22]$.

\section{ENVIRONMENTAL FACTORS AND WORK-FAMILY BALANCE}

The requirements of a globalized labor market and family responsibilities demand increasingly more time and effort. Indeed, personal and family well-being is associated with a favorable and understanding work environment [6, 20]. Increased stress and dissatisfaction appear in the presence of a lack of understanding from superiors, with irregular hours, and with role ambiguity $[23,24]$. These sources of stress explain the difficulty of reconciling domestic roles such as caring for children, which is the main difficulty documented among nurses $[25,26]$. Furthermore, in a phenomenological qualitative study conducted among 13 full-time senior nurses, Firman and colleagues, 2008 [27] reported that a high level of responsibility is associated with a high level of stress and that this has an impact on interpersonal relationships in the workplace.

Indeed, a preoccupation is observed among companies for developing strategies to facilitate this balance and to provide a measure of well-being for employees [20, 28-30].

\section{WORK-LIFE BALANCE AND LIFE HABITS}

According to various authors [20, 31-34], work-family balance is not a simple matter, and the tension that exists between these spheres (work and family) is likely to become a source of conflict. Some studies show that family meals engender good relationships within the family by helping to develop parent/child emotional relationships and encouraging family activities $[2,35,36]$. At the same time, a lack of time and energy is a barrier in the lives of parents, especially with regards to buying groceries and preparing healthy meals thus probably contributing to eating frozen foods or eating out more often [35]. Furthermore, overwhelmed by an inability to manage family responsibilities and thus subject to more or less high levels of stress, parents see their influence on their children decrease, which causes degradation in the parent/child relationship [37-39]. According to Statistics Canada, 1995 [40], parents are largely in agreement with the statement that their children are more prone to school failure when both parents work full time. Moreover, the topics of food and entertainment are not well developed in the articles, although allusions to these topics are sometimes made in studies by Statistics Canada. On the other hand, reflecting on the concept, Rochette and colleagues, 2006 [41] propose that for participation to be optimal there must be perfect congruence between reality (how the activities of daily life and social roles are accomplished) and expectations (how one wishes or expects the activities of daily life and social roles to be accomplished). Regarding social participation, we know that it is essential today to find a balance between the two poles: the family (which is a place of socialization and emotional relationships) and work (which provides social status, financial resources, and a degree of autonomy).

Fig. (2) illustrates the importance of considering the concept of social participation in a holistic manner given the multiple factors that contribute inter-influentially to its complexity. Anchored in the DCP, this figure illustrates the personal factors (internal) and environmental factors (external) identified in the literature as interacting with the accomplishment of a person's various life habits.

The purpose of this study is to explore the perception of rehabilitation professionals regarding their optimal social participation based on work-family conciliation, and the factors they identify as influencing this participation.

\section{METHODOLOGY}

\section{Study Design}

A qualitative method adopting a phenomenological perspective was used. This method was favored amongst other qualitative methods as it allows studying the meaning given to a phenomenon, in this case, the daily lives of rehabilitation professionals who have one or more children. This method combines a scientific analysis at the level of awareness and the object, allowing in-depth and accurate study of human phenomena, or in a broader sense, one that combines practice and theory [42].

\section{Targeted Population}

The targeted population consisted of rehabilitation professionals (doctors, nurses, occupational therapists, physiotherapists, psychologists, social workers, speech language therapists, and nutritionists) having one or more children under 18 . The rationale to include only participants with children was to study this particular common subgroup in the rehabilitation sector who may share similar daily challenges. The inclusion and exclusion criteria favored a variety of experiences (age, gender, marital status, and profession or program). For the diversity of the sample to be effective, purposive sampling was used among the various professionals according to specific variables. Participants who could not speak French were excluded.

\section{Recruitment and Conduct of the Study}

Recruitment was carried out at two rehabilitation centers: one center provided out-patient services, and the other provided in-patient services. An email invitation was sent to all employees of both targeted sites by site research coordinator (not involved in the study), including information and consent form. Those interested in participating were met individually. Before collecting any data, consent form was read and all questions answered. Once consent form was signed, socio-characteristics of participants were collected followed by the interview per se. All interviews were conducted by first author.

The study was approved by the research ethics committee of the Centre for Interdisciplinary Research in Rehabilitation of Greater Montreal. 


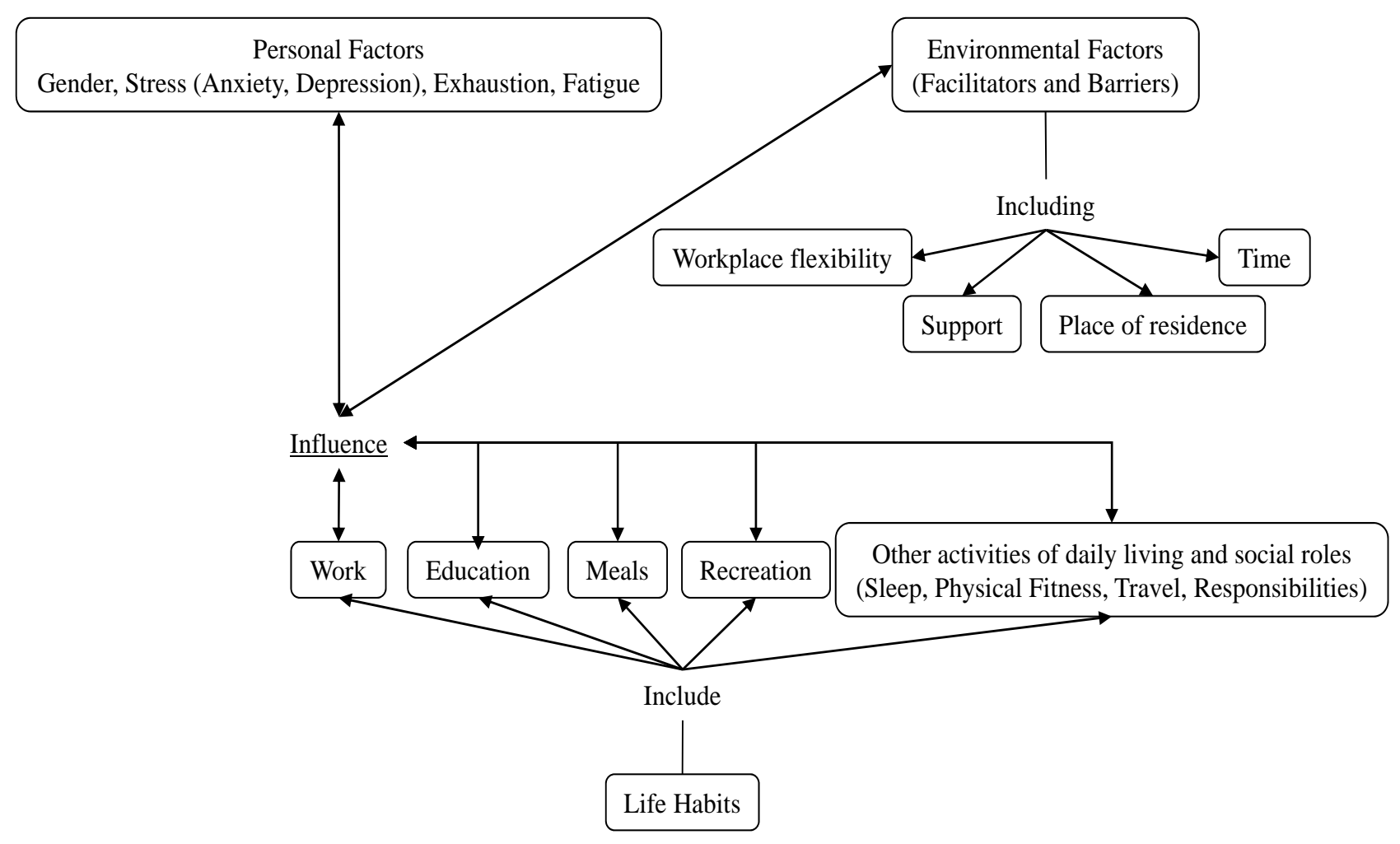

Fig. (2). Summary of factors identified in the literature as influencing the accomplishment of life habits.

\section{Data Collection}

An interview guide was developed to allow exploring the daily lives of the participants both at home and at work. Examples of questions were the following: 1) Describe to me a typical weekday, weekend day, or day off; 2) Tell me about your leisure activities: activities that you like to do, that make you feel good; 3) In an ideal world, what would you do differently in your daily life? (Examples of sub-questions: What do you feel prevents you from doing so (barriers)? What do you feel allows you to do so (facilitators)? 4. Tell me what happens at work when, for example, one of your children is sick and is unable to go to school or daycare or when, for example, the school or daycare is on strike.

The data collected was audio-recorded and transcribed in full (verbatim). Data management was carried out using QDA Miner software.

\section{Sample Size}

The sample size $(\mathrm{n}=13)$ was justified by the exploratory nature of the study and the qualitative design, which does not require a large sample size [42].

\section{Data Analysis}

Close analysis was carried out in various stages. Summaries of each interview were produced to capture overall meaning as related to the phenomenon (first impression, surface meaning). Verbatim transcriptions of the interviews were subjected to exhaustive coding by attaching labels to units of meaning formed by words, sentences, or paragraphs and by grouping the labels into categories to achieve a data classification grid inspired by the underlying conceptual model of the study, the DCP, but not limited by it. Analysis was carried out systematically by first author to achieve a better understanding of the facts. A proportion of the analysis (approximately 10\%) was coded by another team member blind to the identity of participants and to the first author analysis for validation.

\section{RESULTS}

The sample $(\mathrm{n}=13)$ consisted of 12 women; all participants were married except ID 12, who was separated (see Table 1).

The model underlying the study (DCP) was used as a tool to support the analysis. The principal and critical themes emerging from the data were organized according to their link with optimal social participation and according to the personal and environmental factors perceived as influencing this participation.

\section{Optimal Participation}

Three main themes related to optimal participation emerged from the data: meaningful activities accomplished, meaningful activities in an ideal world (expectations), and responsibilities. The theme meaningful activities has several sub-themes such as activities that achieve well-being, including sports, outings with family or friends, time for oneself, or relaxing activities (see Table 2). These activities reflect a form of control that participants have on optimal social participation because they are selected and prioritized in the participants' schedules. In a similar approach, by exploring the optimality from participants, $9 / 13$ were closer to optimality when they told us about their real lives and 
Table 1. Characteristics of Participants $(n=13)$

\begin{tabular}{|c|c|c|c|c|c|c|}
\hline ID & Age & Number of Children (Age in Years) & Profession & Full/Part Time & Travel Time to Work (Minutes) & Institution* \\
\hline 1 & 42 & 2 (4 and 8 years) & Physiotherapist & Full time & 20 & 1 \\
\hline 2 & 38 & 2 ( 7 months and 5 years) & Physiotherapist & Part time & 40 & 1 \\
\hline 3 & 34 & $3(4,6$, and 10 years $)$ & Social Worker & Part time & 4 & 1 \\
\hline 4 & 44 & 2 (10 and 12 years) & Neuropsychologist & Part time & 15 & 1 \\
\hline 5 & 36 & $3(1,3$, and 5 years $)$ & Speech Language Therapist & Full time & 20 & 2 \\
\hline 6 & 31 & 1 (2 years) & Guidance Counselor & Full time & 15 & 2 \\
\hline 7 & 40 & 1 ( 7 years) & Occupational Therapist & Part time & 50 & 2 \\
\hline 8 & 38 & 1 ( 7 years) & Occupational Therapist & Full time & 7 & 2 \\
\hline 9 & 31 & 1 (3 years) & Neuropsychologist & Part time & 45 & 1 \\
\hline 10 & 38 & 2 (2 and 4 years) & Occupational Therapist & Full time & 25 & 2 \\
\hline 11 & 40 & 2 (7 and 11 years) & Physiotherapist & Part time & 30 & 1 \\
\hline 12 & 42 & 1 (1 year) & Social Worker & Full time & 80 & 1 \\
\hline 13 & 33 & 2 ( 2 and 4 years) & Physiotherapist & Part time & 45 & 1 \\
\hline
\end{tabular}

*Institution: Site 1 (in-patient rehabilitation); Site 2 (out-patient rehabilitation).

their wishes. Conversely, for some participants, it was more a question of expectations. Again, these are meaningful activities, but for various reasons they are at the level of desire in terms of their accomplishment in an ideal world.
The third major theme concerns responsibilities, i.e., "obligations" and roles that have varying significance for individuals but, above all, ensure survival as opposed to personal fulfillment. Under this theme, we find the following sub-themes: childrearing, home maintenance (inside and

Table 2. Summary of Themes and Sub-Themes Related to Optimal Participation Illustrated by Verbatim Excerpts

\begin{tabular}{|c|c|c|}
\hline Themes & Sub-Themes & Verbatim Excerpts (Translated from the French) \\
\hline \multirow[t]{4}{*}{ 1. Meaningful activities accomplished } & -Sports & $\begin{array}{l}\text { ID } 6 . \text { "Gym, including zumba. I thinking participating in sports } \\
\text { is really important... it's a priority for me." }\end{array}$ \\
\hline & -Family outings & $\begin{array}{l}\text { ID 7. "We always try to do two weekends a year, and the rest of } \\
\text { time we do occasional outings, and we do a lot of things with } \\
\text { my daughter. My husband sings during the week, and so do I, } \\
\text { and he also does stuff at the Museum of Fine Arts, so we each } \\
\text { have our own activities." }\end{array}$ \\
\hline & -Scheduled personal time & $\begin{array}{l}\text { ID 9. "I like to treat myself to a massage. It's relaxing and really } \\
\text { contributes to my well-being." }\end{array}$ \\
\hline & -Relaxing activities & $\begin{array}{l}\text { ID 3. "I like to pray. When I have time, I sneak into a special } \\
\text { Mass or the Oratory alone or wherever. It makes me feel good." }\end{array}$ \\
\hline 2. Meaningful activities in an ideal world & -Expectations & $\begin{array}{l}\text { ID 4. "I would like to join a yoga class. I've already done kung } \\
\text { fu. I would like to do physical activities with my family, but for } \\
\text { relaxation." } \\
\text { ID 6. "I would probably work three days a week, and I would } \\
\text { probably work shorter days, perhaps six or seven hours per day." }\end{array}$ \\
\hline \multirow[t]{4}{*}{ 3. Responsibilities } & -Childrearing & $\begin{array}{l}\text { ID 13. "My husband's number one task is mathematics. So, he } \\
\text { supervises the kids' homework and helps them when they need } \\
\text { it, and I help them with French. So, we divide the tasks..." }\end{array}$ \\
\hline & -Housework & $\begin{array}{l}\text { ID 11. "If we don't want to do housework or maintenance on the } \\
\text { weekend then we have to do it during the week, which means } \\
\text { vacuuming, laundry, tidying up, washing the floor, etc." }\end{array}$ \\
\hline & -Meal preparation & $\begin{array}{l}\text { ID 9. "I would say that meal preparation and menu planning is } \\
\text { mostly my job. My husband will make a meal on occasion when } \\
\text { I'm running a little late." }\end{array}$ \\
\hline & -Travel related to children's activities & $\begin{array}{l}\text { ID 5. "I leave the daycare at five thirty, and I have to go to the } \\
\text { school, and I arrive at the school at a quarter to six, and the } \\
\text { daycare closes at six o'clock." }\end{array}$ \\
\hline
\end{tabular}


outside), meal preparation, and travel related to children's activities (daycare/school).

\section{Factors Perceived as Influencing Optimal Participation}

Five environmental factors related to optimal participation emerged from the data: financial aspects, spousal support, time, flexible work schedules, and family organization. These factors were seen as either facilitators or barriers, allowing a better understanding of social participation among rehabilitation professionals. The participants associated financial aspects with time spent at work. Work as a source of income was seen by the participants as a motivation for working full time, although several mentioned that in an ideal world they would work part time but couldn't afford to do so because of the resulting decrease in income. Participants also wanted more time to spend with their children, but the potential reduction in income was a hindrance to accomplishing this social role. Spousal support, which is an important factor when present, facilitates the couple's relationship through sharing of responsibilities (survival activities), thus freeing time to accomplish meaningful activities related to personal fulfillment. Time, which is managed by each person in his or her own way, sometimes, allows participants to combine several life habits such as bicycling to work, which promotes physical activity, thus allowing participants to optimize their time. A flexible work schedule, which may be implemented in the workplace, facilitates the daily planning of professionals, gives them a certain amount of autonomy, and make them feel valued because of this measure of trust. Family organization, e.g., when individuals systemically organize and plan their time off work, emerged as a determining facilitator of optimal social participation because it promotes a better understanding of what actually can be accomplished in a 24hour day and results in expectations being more consistent with these possibilities (see Table $\mathbf{3}$ ).

In the results, however, no personal factors emerged as directly influencing optimal social participation but emerged, rather, as outcomes. For example, fatigue may be a consequence of an increased workload that participants must assume because of their financial situation. In the presence of fatigue, some meaningful activities are put aside for rest, thus contributing to sub-optimal social participation.

\section{DISCUSSION}

The purpose of this study was to explore the perception of optimal social participation among rehabilitation professionals based on work-family conciliation, and the factors they identify as influencing this participation.

Reflecting on the concept, Rochette and colleagues, 2006 [41] propose that for the participation to be optimal there must be perfect congruence between reality (how the activities of daily life and social roles are accomplished) and expectations (how one wishes or expects the activities of daily life and social roles to be accomplished). In our study, participants' expectations regarding life habits they desired in an ideal world emerged as a major theme. In interviews, we were able to explore optimal participation by addressing the lives of participants compared to how they would like their lives to be in an ideal world, which allowed us to detect, for some, a difference between real life and wishes. Depending on what they told us, how they live, and how they would like to live, we noted that some participants $(9 / 13)$ were closer to this optimal participation. It seemed important to include meaningful activities in the lives of each individual that promote personal fulfillment since these correspond to optimal social participation. These activities, for the most part, are neither in the realm of work nor in the realm of family life but are nevertheless interrelated with them. This illustrates, therefore, the complexity of everyday life and the importance of approaching it as a whole, rather than in a segmented mode.

Among the environmental factors that emerged in our study, time was an important element, playing a major role in the work-family balance. Time is also mentioned in several studies [31, 43-45] as a determining factor in reconciling family and professional life. These studies demonstrate the difficulty that some workers have in managing their time. Lack of time emerged as a major obstacle to optimal social participation. Time is reported in several studies $[20,31,32,43,45,46]$ as a barrier to workfamily balance. However, time is equal for everyone. Indeed, anywhere in the world, a day comprises 24 hours. What differs from one individual to another is how time is managed and used and which activities (professional, family, or personal fulfillment) are prioritized. Thus, while time is not a modifiable factor per se, the way it is managed is. In

Table 3. Factors Influencing Optimal Participation Illustrated by Verbatim Excerpts

\begin{tabular}{|c|c|}
\hline Factors & Verbatim Excerpts \\
\hline Financial aspects & $\begin{array}{l}\text { ID } 7 . \text { "Of course the ideal would be to work a little less and spend more time with my family, but there's } \\
\text { the financial aspect to consider." }\end{array}$ \\
\hline Spousal support & $\begin{array}{l}\text { ID 8. "My husband's in school, so we share everything four evenings a week; two evenings I'm with the } \\
\text { kids more, and the other two evenings he is, so I can leave the house to work out..." }\end{array}$ \\
\hline Flexible schedule at work & ID 3. "What's great is the flexibility I have to manage my schedule as I see fit; it's fantastic." \\
\hline $\begin{array}{l}\text { Time } \\
\text { - Travel distance }\end{array}$ & $\begin{array}{l}\text { ID 6. "We're less than three minutes on foot, so everything is easy... a quick visit to the park before } \\
\text { supper, working out at the gym... So it's pretty easy to organize leisure and sports activities considering } \\
\text { that." }\end{array}$ \\
\hline - Possibility of combining several life habits & ID 7. "I go to work by bike, but it still takes time; it's quite far, it takes me about 45 minutes." \\
\hline - Time management & $\begin{array}{l}\text { ID 1. "It's because there's not enough time. We come home, make supper, do homework. In the evening } \\
\text { sometimes there's shopping to do, laundry, preparing stuff for the next day... There's not enough time in } \\
\text { the day." }\end{array}$ \\
\hline
\end{tabular}


this sense, time management related to family organization and family structure allows one to have a better idea of what can be accomplished in a single day (taking into account travel time), which influences how personal expectations are more in line with reality. At the same time, in many workplaces, the organization of work (including professional time management) leaves less room for decision-making activities providing personal fulfillment but concentrates on the carrying out of responsibilities, unlike time off work, where individuals must make choices related to the meeting of their responsibilities and the prioritization of meaningful activities providing personal fulfillment.

Among the factors emerging as having an influence on optimal participation, we noted in our study that family organization stood out as particularly significant. Indeed, for participants who have a well-structured family organization, there is relatively close similarity between tasks that must be done and tasks that can be done. As such, this factor is a facilitator in our study and has not been mentioned in other studies. By personal life we mean life outside work, and if one is not aware of the need for organization, it is very likely that one will end up with unrealistic expectation by trying to do too many things in a 24-hour day. Other factors of an environmental nature emerging from our results are also reflected in the literature as potential facilitators, including financial aspects [47], flexible work schedules [29, 48-50], and policies put in place $[51,52]$.

In the interviews, we noted that rehabilitation professionals would like to see measures that facilitate their family lives. The measures they cited (workplace daycare, flexible schedules, etc.) would result in more useful and satisfactory arrangements at home. This idea is in line with a study by Frone and colleagues, 2003 [53], which mentions that recent research on work-family balance is increasingly interested in the implementation of "policies." Today, many efforts by governments demonstrate an interest in solving various problems in the workplace, and the measures put in place suggest organizational support. However, a study by Closon, 2009 [51] highlights the importance of introducing policies to support work-family balance, although the results show that having a better position is not necessarily associated with job satisfaction. This study shows, in fact, that support policies are not a solution to conflicts but help to resolve conflicts. Indeed, our results show that such policies (e.g., daycare, flexible work schedules/leave) are greatly appreciated by the participants since these services are seen as facilitators and help the participants in their daily planning; for example, flexible work schedules make it easier to organize medical appointments for children. Such policies, therefore, do not appear as solutions but as facilitators.

It is important to note that some studies [18] take into account that women are increasingly part of the labor market. The difficulties of achieving a satisfactory balance within couples are compounded because women are at home less, which means adapting as a family and sharing housework. The sample in our study consisted primarily of women, who mentioned that family responsibilities related to children and the home, for example, are often shared within the couple. Imbalance in the division of labor between women and men at home highlights the importance of spousal support, which emerged as an important influence, particularly regarding the sharing of family responsibilities. This is consistent with other studies [17, 18, 54] showing that an equitable division of labor is desirable for women. A better representation of men would have been useful in our study to document their perceptions about this division of labor. Nevertheless, the gender ratio in our sample reflects the proportion of individuals working in the field of rehabilitation.

\section{Strengths and Limitations of the Study}

The main strengths of this study lie in the descriptive and analytical method of in-depth interviews to identify important aspects in the daily lives of the participants. The inclusion criteria allowed us to effectively target the population. In addition, our study is the first to address this issue among rehabilitation professionals and to analyze the phenomenon as a whole, rather than in a fragmented fashion. Our study also has certain limitations. The relatively small sample size does not allow for generalization to all professions including the rehabilitation one, and the underrepresentation of men in the sample shows that it is impossible to confirm the different perceptions that exist between men and women, since the majority was women.

\section{CONCLUSION}

This innovative study helps to highlight the concept of optimal social participation and the factors perceived as influencing this participation by rehabilitation professionals working in a demanding health-care system. Despite the difficulties encountered in their daily lives, which sometimes result in a lack of consistency between their actual and desired lives, rehabilitation professionals are able to accomplish their activities of daily living and their social roles. Social participation is optimal when individuals have the opportunity to accomplish, according to their expectations, both their responsibilities and their meaningful activities providing personal fulfillment. Work-life conciliation is a complex phenomenon that deserves as a whole, rather than segmented approach. In this sense, other studies may enhance current knowledge on the subject by showing how to improve the quality of services provided to patients by first improving the quality of life of rehabilitation professionals.

\section{CLINICAL MESSAGES}

- Optimal participation is perceived as the ability to carry out important activities while fulfilling one's various responsibilities.

- Family organization emerged as an environmental factor which greatly influences optimality of participation.

- Work-life balance is a complex phenomenon that should be studied holistically rather than in a segmented mode.

\section{CONFLICT OF INTEREST}

The authors confirm that this article content has no conflicts of interest. 


\section{ACKNOWLEDGEMENTS}

This study was carried out with funding from the Centre for Interdisciplinary Research in Rehabilitation of Greater Montréal and the Centre de réadaptation Lucie-Bruneau provided to AR, who was also supported by a Junior Career Award from the Fond de Recherche du Québec-Santé (FRQS).

\section{REFERENCES}

[1] Fougeyrollas P, Noreau L, Bergeron H, Cloutier R, Dion SA, StMichel G. Social consequences of long term impairments and disabilities: conceptual approach and assessment of handicap. International journal of rehabilitation research Internationale Zeitschrift fur Rehabilitationsforschung. 1998; 21(2): 127-41.

[2] Concilier le travail et la famille: enjeux et options. Conference Board of Canada; 1994; Ottawa.

[3] La difficulté de concilier travail-famille: ses impacts sur la santé physiques et mentales des familles québécoises. Québec: INSPQ, 2005.

[4] Glezer HW, I. Work and family life: reciprocal effects. Family Matters 1999; 52: 69-74.

[5] Maslach C, Jackson SE. Maslach Burnout Inventory manual. $3^{\text {rd }}$ ed. Palo Alto Calif: Consulting Psychologists Press 1996.

[6] Matthews LSC, K. A et Wickrama, S. Work-family conflict and marital quality: Mediating processes. Soc Psychol Quart 1996; 59(1): 62-79.

[7] Frone MRR, Cooper M. Relation of work-family conflict to health outcomes: a four-year longitudinal study of employed parents. J Occup Organ Psychol 1997; 70: 325-35.

[8] Allen TD, Herst DEL, Bruck CS, Sutton M. Consequences associated with work-to-family conflict : a review and agenda for future research. J Occup Organ Psychol 2000; 5(2): 278-308.

[9] Canivet C, Östergren P-O, Lindeberg SI, Choi B, Karasek R. Conflict between the work and family domains and exhaustion among vocationally active men and women. Soc Sci Med 2010; 70(8): 1237-45.

[10] Beaudin MP, G. Sans emploi, peut-on vivre? Fides, Eds. Québec1994.

[11] Descarries F, Corbeil C, Eds. Ré-conciliation famille-travail: les enjeux de la recherche. 62 Congrès de L'ACFAS; 1995 mai1994; L'UQAM.

[12] Galambos NLS, Akmeida HA, Kolaric GC. Parent'A work overload and problem behavior in young adolescents. J Res adol $1995 ; 5(2): 201-23$

[13] Grzywacz JG, Frone MR, Brewer CS, Kovner CT. Nuantifying work-family conflict among registered nurses. Res Nurs Health 2006; 29(5): 414-26.

[14] Barrette J. Conciliation travail-famille: qu'en savons-nous vraiment? Ottawa: L'institut Vanier de la famille, 2009.

[15] Cyr MD, H. L'adaptation de femmes professionnelles à la carièrre, à la maternité et aux responsabilités familiales. Revue Candienne de counselling 1991; 25(4): 520-30.

[16] Baudoux C. Famille et carrière: le cas des gestionnaires féminines en éducation. Recherches féminites 1992; 5(2): 55-78.

[17] Descarries F, Corbeil C. Articulation famille/travail: quelles réalités se cachent derriére la formule? Espace et temps de la maternité 2002: 456-77.

[18] Les femmes sur le marché du travail: évidences empirique sur le rôle des politiques économiques et déterminants dans les pays de l'OCDE. Revue économique de l'OCDE 2003.

[19] Leitier MP, Durup MJ. Work, home and in-between: A longitudinal study of spillover. J Appl Behav Sci 1996; 32(1): 29-47.

[20] Kossek EE, et Oseki C. Work-family conflict, policies and the joblife satisfaction relationship: a review and directions for organizational behavior-human resources research. J Appl Psychol 1998; 83(2): 139-49.

[21] Coverman S. Role overload, role conflict and stress: adressing consequences of multiple role demands. Soc Forces 1989; 67(4): 965-82.

[22] MacEwen KE, Barling J. Daily consequence of interference with family and family interference with work. Work Stress 1994; 8(3): 244-54.

[23] Business Work-Life study.Families and Work Institute. New York: 1998.
[24] Tremblay DG, Loreto di M, Genin E. Le soutien organisationnel à la conciliation emploi-famille: quelques observations dans le secteur policier au Québec. Montréal: Téluq-UQAM, 2009.

[25] Hirsch BJ, Rapkin BD. Multiple roles, social networks and women's well-being. J Person Soc Psychol 1986; 51(6): 1237-47.

[26] Duquette A, Kerouac S, Sandhu BK, Beaudet L. Factors related to nursing burnout: a review of empirical knowledge. Issues Ment Health Nurs 1995; 15(4): 337-58.

[27] Firman MWB. When caretaking competes with care giving: a qualitative study of full-time working mothers who are nurse managers. J Nurs Manag 2008; 16: 858-67.

[28] Glass JL, Finley A. Coverage and effectiveness of family responsive workplace policies. Hum Resour Manag Rev 2002; 12: 313-37.

[29] Anderson SE, Coffey BS, Byerly RT. Formal organizational initiative and informal workplace practices: links to Work-family conflict and job-related. J Manag 2002; 28(6): 787-810.

[30] Batt R, Valcour PM. Human resources practices as predictors of work-family outcomes and employee turnover. Ind Relat 2003; 42: 189-220.

[31] Frone MR, Russell M, Cooper ML. Antecedents and outcomes of work-family conflict: testing a model of the work-family interface. J Appl Psychol 1992; 77(1): 65-75.

[32] Duxbury LE, C Higgins. Gender differences in work-family conflict. J Appl Psychol 1991; 76(1): 60-74.

[33] Carlson DS, Kacmar KM, Williams LJ. Construction and initial validation of a multidimensional measure of work-famliy conflict. J Vocat Behav 2000; 56: 336-53.

[34] Greenhaus JH, Beutell NJ. Sources of conflict between work and family roles. Acad Manag Rev 1985; 10: 76-88.

[35] Canada S. Point de vue des consommateurs sur une saine alimentation. Statistique Canada, 2003.

[36] MacBridge-King JL, Ed. Concilier le travail et la famille: un défi de taille dans les années 1990. Conference Board du Canada; 1990; Ottawa.

[37] Crnic KA, Greenberg MT, Slough MN. Early stress and social support influences on mothers' and high risk infants' functioning in late infancy. Infant Ment Health J 1986; 7(1): 19-33.

[38] Nievar MA, Luster T. Development processes in african american families: An application of McLoyd's theoretical model. J Marriage Fam 2006; 68: 320-31.

[39] Gutman LM, McLoyd VC, Tokoyama T. Financial strain, neighborhood stress, parenting behaviors and adolescent adjustment in urban african american families. J Res Adol 2005; 15(4): 425-49.

[40] Canada S. Available at www.statcan.gc.ca. 1995.

[41] Rochette A, Korner-Bitensky N, Levasseur M. Optimal participation: a reflective look. Disabil Rehab 2006; 28(19): 1231-5.

[42] Poupart J, Deslauriers J-P, Groulx L, Laperrière A, Mayer R, Pires A. La recherche: Enjeux épistémologiques et méthodologiques. Morin G, Ed. Montréal 1997.

[43] Lee K, Carswell J J, Allen, NJ. A meta-analytic review of occupational commitment: relations with person and work-relate variables. J Appl Psychol 2000; 85(5): 799-811.

[44] Frone MR. Work-family balance.In: Quick JC, Tetrick LE, Eds. Handbook of occupational health psychology. washington DC: American Psychological Association 2003; pp. 143-62.

[45] Stephens GK, Sommer SM. The measurement of work to family conflict. Educat Psycholog Measur 1996; 56(3): 475-86.

[46] Netemeyer RG, Boles JS, McMurrian R. Development and validation of work-family conflict and family-work conflict scales. J Appl Psychol 1996; 81(4): 400-10.

[47] Berkowitz L, Fraser C, Treasure PF, Cochran S. Pay, equity, job gratifications and comparisons in pay satisfaction. J Appl Psychol 1987; 72(4): 544-51.

[48] Boulanger S. La réduction du temps de travail: une solution aux difficultés de conciliation travail-famille. Québec: Université Laval 2001.

[49] Casper WJ, Buffardi LC. Work-life benefits and job pursuit intentions: the role of anticipated organizational support. J Vocat Behav 2004; 65(3): 391-410.

[50] Thomas L, Ganster D. Impact of family supportive work variables on work-family conflict and strain: a control perspective. J Appl Psychol 1995; 80: 6-15. 
[51] Closon C. Work-life balance: Satisfaction and perception of conciliation politics on determining variables? Pratiques Psychologiques 2009; 15(2): 203-12.

[52] Tremblay DG, Najem E, Paquet R. Articualtion emploi famille et temps de travail: de quelles mesures disposent les travailleurs canadiens et à quoi aspirent ils? Note de recherche de la chaire de recherche du Canada sur les enjeux socio-organisationnels de l'économie du savoir, 2005.

[53] Frone MR, Quick JC,Tetrick LE. Work-family balance. Handbook of occupational health psychology. Washington: American Psychological Association 2003; pp. 143-62.

[54] CFE Cdlfedle-. Famille et travail, deux mondes à concilier. In: CFC, Ed. Québec1999.

Received: July 9, 2012

Revised: December 6, 2012

Accepted: December 23, 2012

(C) Braga and Rochette; Licensee Bentham Open.

This is an open access article licensed under the terms of the Creative Commons Attribution Non-Commercial License (http: //creativecommons.org/licenses/by$\mathrm{nc} / 3.0 /$ ) which permits unrestricted, non-commercial use, distribution and reproduction in any medium, provided the work is properly cited. 